\section{Research Article}

(C) 2021 S. S. Makgopa.

This is an open access article licensed under the Creative Commons Attribution-NonCommercial 4.o International License (https://creativecommons.org/licenses/by-nc/4.o/)

\title{
Drivers of Service Innovation in Service Organisations
}

\author{
Dr. S. S. Makgopa \\ Directorate: Curriculum Development and Transformation, \\ University of South Africa, PO Box 392, UNISA, South Africa, ooo3
}

DOI: https://doi.org/10.36941/ajis-2021-0037

\begin{abstract}
Service organisations are faced with intense competition and are relying on service innovations to achieve a competitive advantage. The purpose of this study was to investigate the drivers of service innovation in service organisations. Complexity Theory is adopted as the underlying conceptual lens to answer the research questions and attain the research objectives. A qualitative research method was followed to achieve the research objective. In-depth interviews were conducted to collect primary data with service managers and marketing personnel of service organisations. The primary data in this research paper were analysed using a content analysis method with the aid of Atlas.ti version 8. The results of this study revealed that the level of competition in the industry, and customers' changing behavior. In addition, this study uncovered the key organisations' resources that serve as key drivers of service innovation in service organisations. This paper provides recommendations to managers in service organisations and directions for future research on service innovation.
\end{abstract}

Keywords: competitive advantage, content analysis, business performance, service innovations, service organisation, qualitative research

\section{Introduction}

The business environment in the 21st century is characterised as competitive, as organisations have recognised the need to innovate frequently and provide new processes and better services to customers. Organisations can achieve a competitive advantage by possessing competencies, resources and capabilities that are unique, valuable and difficult to imitate by other organisations (Bellini, Dell'Era, Frattini \& Verganti, 2017). However, the realisation of a competitive advantage depends on the organisation's innovative capabilities and resources (Yanadori \& Cui, 2013). Developing and implementing innovation strategies is believed to assist in improving organisations' business performance by increasing market share and providing the organisation with a competitive advantage (Prajogo, 2016). Therefore, innovation - including service innovation - is important in adopting a market-driven approach that contributes towards a competitive advantage over competitors and business growth in organisations.

According to Van Tonder, Petzer and Van Zyl (2017), the level of competition between service organisations is increasing in South Africa and in other parts of the world, as these organisations operate in a dynamic and competitive business environment. The critical question in service innovation research is whether service innovations within service organisations differ from innovations in 
manufacturing organisations. This paper aims to fill the gap in literature by focusing on the key drivers of service innovation in service organisations, since most of the previous studies have focused on product innovations in manufacturing organisations.

\section{Theoretical Background and Literature Review}

This section reviews definitions of key concepts to make this research understandable, as well as previous studies to illustrate the gap to be filled by this research.

\subsection{Defining service innovation}

Durst, Mention and Poutanen (2014) demonstrate that "service innovation" is an ambiguous term in literature and that there is a fragmented understanding of the concept and the impact on business performance. According to Kindström, Kowalkowski and Sandberg (2013:1064), organisations that aim to manage the complexities associated with service innovation and take full advantage of the service innovation benefits must address the wide range of factors related to service delivery. This implies that service innovation should be perceived as multidimensional, taking into account service innovation design and implementation. On the other hand, Brown and Osbourn (2013) define "innovation" as "the intentional introduction and application within a role, group or organisation of ideas, processes, products or procedures, new to the relevant unit of adoption, designed to meaningfully benefit the individual, the group, organisation or wider society". Considering these definitions, "service innovation" in this paper will be defined as follows: Service innovation refers to new idea generation and implementation of intentional incremental innovations that are new to the market which include new processes, new products or service on the existing services, new procedures, designed to benefit the customers, the organisation, and other stakeholders.

\subsection{Benefits of service innovation}

Innovation in general allows organisations to develop products or services which are unique from competitors aiming to add value for customers (Clarke \& Adler, 2016). Being specific, service innovation has become an increasingly important concern in order to create innovative service activities and the implementation of the market concept, along with business activities. Chen, Wang, Huang and Shen (2015) point out that service innovation is a critical factor for organisations in maintaining and sustaining a competitive advantage in an increasingly service-organisation context. The service sector is viewed as important for global economic activity and is considered a primary source of value creation (Zhang et al., 2016), which is derived from innovation and thus increases organisational business performance. According to Zhang et al. (2016), service innovation requires that customers, employees and suppliers be integrated in developing service innovation that will satisfy customers' needs and serve as a solution. This implies that service innovation should aim to offer new solutions to customers' needs.

\subsection{Drivers of service innovation}

A key element that drives organisations to innovate continuously is related to both micro- and macroeconomic forces that guide their strategic decisions by allowing organisations to realise opportunities and overcome challenges. Al-Ansari, Pervan and Xu (2013) point out that the key drivers of innovation include the organisation's management, customers, technology and employees. Innovation capabilities such as technologies, networks, learning, processes, strategy and culture have also been identified as key drivers of innovation (Ferreira et al., 2015). Pantano and Viassone (2014) suggest that the adoption of innovation in a retail setting is determined by organisational innovativeness (ability to innovate, which is linked to the capacity to adopt an innovation before the 
competitors); human capital (employees and managers, in terms of openness to novelty, willingness to be the first adopters in a specific domain and propensity to engage new ideas for improving organisational processes); progress in technology; organisational characteristics (financial resources, organisational size and age); and market orientation (market intelligence, customer orientation and interfunctional coordination). Sundbo, Sundo and Henten (2015) posit that service innovation requires mutual empathy between employees and customers, and that if employees invest in time and keenness to inovate, these can serve as drivers for innovation. The point here is that, in order to innovate within the organisation, the identification of potential innovation opportunities is necessary.

\subsection{Complexity theory}

This study adopted the Complexity Theory which holds that organisations can naturally develop effective strategies, structures, and processes and self-adjust to new strategies and environmental changes. According to Levin (1999), the key fundamental inferences arising from Complexity Theory is that order naturally occurs in systems, no matter how simple, complex, non-linear, or chaotic the system is. The point is that natural order evolves through self-organisation. In a manner that when a system is open to receiving energy from the outside, it will tend to create order, and when a system becomes closed, it will deteriorate into maximum disorder and chaos. The approach advocated in this study is based on the principles and concepts of the Complexity Theory. The argument in this study is that employees (as agents) facilitate, guide, and set the boundary conditions within which effective strategies can take place taking into account environmental changes that serve as drivers of service innovations. This study further supports the Complexity Theory by arguing that the complex and dynamic nature of the business environment presents both opportunities and threats.

\subsection{Previous studies on service innovation}

Al-Ansari et al. (2013) explored the innovative characterstics of organisations and the link between innovations and business performance. The results of the preceding the aforementioned study revealed that managers have different perceptions of innovative characteristics and that innovation has a moderate impact on business performance. Pantano and Viassone (2014) investigated the technologybased innovations in a retail setting and how these are linked to internal characteristics of organisations, and the results of their study confirmed the limited diffusion of new technologies applied to points of sale. However, retailers showed an interest in the adoption of technology-based innovations.

Ferreira et al. (2015) investigated the determinants of innovation management and the implications of these determinants on business performance. The results of this study identified innovation capabilities such as technologies, networks, learning, processes, strategy and culture as key determinants of innovation and revealed conflicting results regarding the relationship of these determinants and business performance in different sectors. Kindström et al. (2013) explored how product-centric organisations can focus on service innovation by adding services to their portfolio. The results revealed that a major challenge associated with the shift from product-centredness to productand-service orientation is the management of the essential dynamic capabilities of sensing, seizing and reconfiguring that are needed for service innovation. Kindström et al. (2013) identifies key microfoundations forming the basis of successful realignment of an organisation's dynamic capabilities in order to achieve a better fit with service innovation activities.

Witell et al. (2015) explored the service logic model and this study argues that under such constraints, a formalised new service development process could be counterproductive and a bricolage perspective might better explain service innovation in resource-constrained environments. In addition, this study proposes that four critical bricolage capabilities (i.e. addressing resource scarcity actively, making do with what is available, improvising when recombining resources, and networking with external partners) influence service innovation outcomes. In another study, Khan and Naeem (2018) 
examined the relationships between quality practices, service innovation and organisational performance. Quality practices were divided into soft and hard quality practices. Initially, the impact of soft quality practices on hard quality practices was studied; then the impact of each of these quality practices on service innovation and organisational performance was examined. The study tested if hard quality practices mediate the effect of soft quality practices on service innovation and organisational performance. The mediating impact of service innovation on the quality practices and organisational performance relationship was also tested. The results of the study revealed that quality practices improve service innovation and organisational performance, while service innovation positively influences organisational performance.

Mennens et al. (2018) identified different factors that enable organisations to attain a competitive advantage based on service innovation and to improve business performance. Mennens et al. (2018) identified absorptive capacity and employee collaboration in an organisation as critical factors in service innovation, as well as the organisation's search breadth. The findings of this study confirm that employee collaboration and search breadth have positive effects on an organisation's potential absorptive capacity, whereas employee collaboration reinforces its realised absorptive capacity. In another study, Bustinza et al. (2017) explored empirically whether external collaborative service development and provision and industrial R\&D intensity help to explain the complex relationship between product-service innovation (servitisation) and performance. This study confirmed that organisations in R\&D-intensive industries are more likely to benefit from implementing service provision than organisations in other sectors because of industry dynamics and reduced customer uncertainty. In recent study, Kitsios and Grigoroudis (2020) assessed the relationship between service innovations and business performance in tourism sector and the results also confirmed a correlation between the two variables. In addition, these results discovered that service innovation should be included as a strategic tool to assess differentiation effort in this sector (Kitsios \& Grigoroudis, 2020).

It is clear that today's business environment characterised by the rapid changes, such as have a direct impact on businesses' operation. This makes it necessary for organisations to continuously seek new ways to differentiate their service offerings (Andreassen et al., 2016). Therefore, taking into account these earlier studies, it is clear that service innovation is not widely addressed or researched in other parts of the world, particularly not in developing countries such as South Africa. In addition, much less research is done in service organisations as compared to product innovations in manufacturing organisations. This study contributes to literature on the topic by focusing on the drivers of service innovation activities in service organisations by using a case study on motor vehicle retailers (MVRs). This paper is in line with the research recommendation by Tseng, $\mathrm{Wu}$, Chiu, Lim and Tan (2019) and Thakur and Hale (2013) that more empirical research is required to identify both exogenous (outside the organisation's discretion) and endogenous factors(within the organisation's control) that enhance service innovation aiming to improve business performance.

\section{Purpose of the Research}

The research objective of this study was to determine the drivers of service innovation practices in service organisations using a case study on motor vehicle retailers (MVRs) in South Africa.

\section{Contributions of the Study}

This study makes significant contribution by adopting a Complexity Theory by investigating the drivers of service innovation. This study aimed to benefit service organisations by expounding the main drivers of service innovation and implementation thereof, and suggesting careful utilisation of resources in planning and creating an internal environment that supports the generation of new service innovation ideas in a dynamic environment that can contribute to improved business performance. This research will assist marketers and managers to make better decisions associated with planning and executing service innovation activities in a dynamic business environment, which could be of benefit to both 
customers and the organisation. Lastly, this paper provides directions for future research on the topic.

\section{Research Methodology}

In this study, the drivers of service innovation in service organisations, using a case os motor vehicle retailers (MVRs), were explored to generate an in-depth understanding. An exploratory qualitative approach was followed in order to address the research objective. Malhotra (2010) indicates that an exploratory research design is useful when the researcher requires more information about a specific problem, an opportunity or a phenomenon. The aim of using a qualitative approach was to collect data more effectively and to gain richer information by enabling participants to express their opinions and share their experiences regarding the drivers of service innovations in service organisations such as MVRs. The target population for this study was the MVRs operating in Gauteng province, South Africa. South Africa was chosen because of its convenience and accessibility to the researcher. Managers or customer-contact employees of MVRs were chosen as the unit of analysis, since they were holders of the data needed to answer the research questions for this research. Eleven participants participated in this study, of which eight were managers of MVRs and three were senior sales executives involved in sales and financing of motor vehicles in their respective MVRs. This sample was sufficient to generate findings, as researchers are permitted to use a small sample in a qualitative study (Brynard \& Hanekom, 2006). A purposive sampling method was used in this study. Purposive sampling means that participants are selected because of some defining characteristics that make them the holders of the data needed for the study (Tustin et al., 2005). The population can be defined as the total group of persons or entities from whom information is required (Tustin et al., 2005). Twenty participants from different MVRs were targeted, although only eleven participants from twenty different MVRs, selling both new and used vehicles, eventually participated in this study. In-depth semi-structured interviews were used to collect the primary data for this study. According to Malhotra (2010), an in-depth interview refers to an interaction between an individual interviewer and a single participant, whereas semi-structured depth interviews allow the interviewer to uncover underlying motivations and probe the participant on a topic. For this study, the researcher used a research guide containing research question topics during the interviews with participants. The researcher used the qualitative content analysis method in this study because it was ideal for the purposes of this research, namely to determine the drivers of service innovation in service organisations such as MVRs.

\section{Findings and Interpretation}

The following two questions were formulated to address the research objective of this study: What are the internal drivers of service innovation activities of MVRs? What are the external drivers of service innovation activities of MVRs? The participants indicated that management support, financial support in the form of budget allocations, internal human resources, external factors such as networks and a need to improve business returns all serve as drivers of service innovations at the MVRs. The verbatim quotations of the participants are provided below to support the findings mentioned in this paragraph.

According to participant 2, all internal sales consultants in his organisation are encouraged to suggest any innovation that has the potential to increase the business performance. Participants 3 and 8 emphasised that internal staff are permitted to present new ideas to management. Participant 3 added that these new ideas are supported if they have the potential to increase business performance provided these ideas are ethical and fall within the framework of the organisation. Participant 7 added that management supports ideas that make business sense in terms of contributing to the business performance. Participant 4 agreed that management supports service innovations in their organisation. According to participant 5, the organisation should employ innovative people, failing which the personnel should be taught to be innovative. Participant 6 indicated that the buy-in of human capital is an important resource for service innovations. 
"Luckily we're part of a big group as well, so from a resource point of view I'm always catered for. The biggest resource that you use is people. You know, your human capital is essential in making, and if you don't have the buy-in of staff you will never make any initiative work." (Participant 6)

Participant 8 indicated that each department in his dealership conducts brainstorming sessions to generate new service innovation activities; some of these ideas are implemented immediately, but within the constraints of the company's rules.

"We do have brainstorm sessions. We do have time to sit and then how to come up with the proper thing for our own because each and every site has got its own department. There is some ideas that they implement with immediate effect. We sit down with dealership principal (mentioned the name) we agree to it all of us, then we get that the following day when we come those rules you have to obey them, you have to continue with them." (Participant 8)

Participant 10 admitted that his dealership is fortunate to have the resources to support innovation and indicated that these resources are shared.

"We're fortunate enough that the resources to our disposal we split amongst the four departments. And so should we need the driver for instance to drop off a customer and we don't have a driver in the service department we then go to the new car department or the used car department and we get a driver from them to assist us to drop off a customer should that be needed. Innovation stage been done, on the top of my heads." (Participant 10)

Participants 2 and 3 added that human resources (internal staff) and the financial resources, including the budget allocations, serve as internal drivers of service innovations in their respective organisations.

"Normally, they say customers do not buy cars, but buy people if they know that you are good they will buy from you, a salesperson is more important than a building." (Participant 2)

"Human being are more important capital, than anything else, systems comes after, take care of people, people will take care of our customers." (Participant 2)

"Well what is nice is that we all come with different brands, the other colleagues are from (mentioned three different motor vehicle brands Audi, mini and I come from Mercedes) we can suggest that I have seen this done and we present and run with it to improve business." (Participant 3 )

"The organisations gives us resources, stock and know how so that we produce results." (Participant 2)

According to participant 2, the internal staff - particularly in terms of their motor retail experience and different backgrounds - are essential in generating service innovation ideas, since they each bring different experiences to the organisation.

"The manager needs to give salespeople a freedom to think, create a happy environment, when they work in happy environment, you need to create an environment that allows people to think freely, people working in a happy environment tend to be creative." (Participant 2)

"A bottom-up approach is always better than top-down approach, staff is encouraged to come up with new ideas." (Participant 2)

"I mean it must be clear beforehand when those people who are employed here they are, you know, we do explain that, you know, this is the kind of business that we want to achieve and what we do this month might be different to what we do next month." (Participant 5)

According to participant 2, a bottom-up approach is important for driving service innovation in his organisation because it keeps the internal staff happy by giving them the freedom to think and be creative. In addition, the participants indicated that competition, new systems and external networks, such as those with manufacturers and customers, serve as the external drivers of service innovation activities in their respective organisations. 
"We have to learn from our competitors, when we check on warranties if the offer warranties on their cars till 200 oookms while you offer 120 ookms, you have to adjust." (Participant 1)

"If you are at the top you cracking from inside and out, and what you look on is what took you to the top, what you do you look on what you other guys around they do, and you counter their actions."(Participant 2)

Externally are the systems, the systems that you bring inside, the motorvade for birthdays, CSI questionnaires that happens every month, which the manufacturer calls customers asks questions such as the dealership provides the service you can trust, does the dealership deliver promises, yes or no." (Participant 2)

"If you come with better ways of doing things, like if a customer do make an application, and they get approval within 30 minutes, that's what customers wants, they say you strike while the iron is still hot, you come and sit down with the financial lady to finalise the deal and get the car." (Participant 2)

"Every month we get manufacturer CSI report, meaning Customer Satisfaction Index so we measure that on how customers are satisfied." (Participant 2)

"Clients are always changing. People are, you know, they are evolving. I'll put it that way and the market is always changing because of that different needs that we have in the dealership and the tighter the competition you also have to stand up. So for us to meet those standards so far, né, what we do is, we focus more on advertising where because of things that are, everything is going up, we focus more on affordability." (Participant 4)

"You have to be always one step ahead and it's very difficult because if you come up with a new plan, within a month someone else has adopted your plan as well." (Participant 6)

"We are more open-minded, right, in terms of doing service innovation initiatives, like ways of doing business and doing deals and all that kind of stuff. I mean, we live in a world where customers are changing, for one and especially like now." (Participant 7)

According to participant 7, open-mindedness does exist in his dealership and service innovations are necessary because customers are always changing. However, participant 10 added that organisations need to develop new ideas for service innovations, while keeping in mind the requests or needs and changing behaviour of customers.

\section{Discussion and Conclusion}

Carlborg et al. (2014:379) claim that service innovation activities are associated more with significant organisational resources, which can be utilised to achieve increased business performance (for example, competitive advantages). Lusch and Nambisan (2015:155) point customers, easy access to resources, increasing resource density, integration of resources and digitalisation as drivers of service innovation activities in organisations. The results of the current study are in agreement with these results of Lusch and Nambisan (2015), since they highlight the role of customers and access to resources - such as competent staff and allocations in the budget - as the drivers of service innovation activities. In addition, the results of the current study add new insights by emphasising the importance of management support in the generation of new service innovation ideas. Moreover, the current study identifies competitors' activities as a source and driver of service innovation activities. Lastly, the results of the current study reveal new systems and external factors - such as networks derived from franchisee and franchisor agreements - to be drivers of service innovations that influence competitive advantage. These results concur with Carlborg et al. (2014) in that service innovations influence business performance, such as competitive advantage.

\section{Managerial Implications}

Managers of MVRs should encourage internal employees to be creative in coming up with service innovation ideas. To that end, resources should be allocated to support brainstorming sessions to stimulate new service innovation ideas. In addition, managers of MVRs should strive to create a conducive working environment that encourages employees to be creative in proposing new service 
innovation ideas that can improve the organisation's business performance. Lastly, managers in service organisations should continue to monitor the international environment to identify any new service innovation ideas that are being introduced by international service organisations in order to assess if these ideas could be adopted and implemented in different contexts.

\section{Future Research Possibilities}

This study identified the drivers of service innovations in service organisations operating in the motor vehicle retail industry in a province of South Africa by using a qualitative research approach. Therefore, future research could be conducted in other industries, other provinces and other parts of the world, using a mixed method research approach in order to quantify the results. The generalisability of the findings of the study is limited, given the nature of the sample used in this study. Therefore, it remains for future studies to determine whether these results would be valid for a larger cross-section of organisations and a similar research approach could be followed in other countries. Finally, future studies could focus on the adoption of technology in improving service delivery in the motor retail sector and other service organisations.

\section{Acknowledgement}

This paper is part of a thesis titled "The influence of service innovation practices on business performance".

\section{References}

Al-Ansari, Y., Pervan, S. \& Xu, J. (2013). Innovation and business performance of SMEs: the case of Dubai. Education, Business and Society: Contemporary Middle Eastern Issues, 6(4), 162-180.

Andreassen, T.W., Kristensson, P., Lervik-Olsen, L., Parasuraman, A., McColl-Kennedy, J.R., Edvardsson, B. \& Colurcio, M. (2016). Linking service design to value creation and service research, Journal of Service Management, 27, 21-29.

Bellini, E., Dell'Era, C., Frattini, F. \& Verganti, R. (2017). Design-driven innovation in retailing: an empirical examination of new services in car dealership. Creativity and Innovation Management, 26(1), 91-107.

Brown, L. \& Osbourn, S.P. (2013. Risk and innovation: towards a framework for risk governance in public services. Public Management Review, 15(2), 186-208.

Brynard, P. \& Hanekom, S.X. (2006). Introduction to research in management related field. $2^{\text {nd }}$ ed. Pretoria Van Schaik.

Bustinza, O.F., Gomes, E., Vendrell-Herrero, F. \& Baines, T. (2017). Product-service innovation and performance: the role of collaborative partnerships and R\&D intensity. RED Management, 49(1), 33-45.

Carlborg, P., Kindström, D. \& Kowalkowski, C. (2014). The evolution of service innovation research: a critical review and synthesis. The Service Industries Journal, 34(5), 373-398.

Chen, Y., Tang, G., Jin, J., Xie, Q. \& Li, J. (2014). CEOs' transformational leadership and product innovation performance: the roles of corporate entrepreneurship and technology orientation. Journal of Product Innovation Management, 31, 2-17.

Clarke, T. \& Adler, J. (2016). Celebrity chef adoption and implementation of social media, particularly pinterest: a diffusion of innovations approach. Int. J. Hosp. Manag. 57, 84-92.

Durst, S., Mention, A.L. \& Poutanen, P. 2015. Service innovation and its impact: what do we know about? Investigaciones Europeas de Dirección y Economía de la Empresa, 21(2), 65-72.

Ferreira, J.J., Fernandes, C.I., Alves, H. \& Raposo, M.L. (2015). Drivers of innovation strategies: testing the Tidd and Bessant (2009) model. Journal of Business Research, 68(7), 1395-1403.

Khan, B.A. \& Naeem, H. (2018). Measuring the impact of soft and hard quality practices on service innovation and organisational performance. Total Quality Management E Business Excellence, 29(11-12), 1402-1426.

Kindström, D., Kowalkowski, C. \& Sandberg, E., 2013. Enabling service innovation: a dynamic capabilities approach. Journal of Business Research, 66(8), 1063-1073.

Kitsios, F.C. \& Grigoroudis, E. (2020). Evaluating service innovation and business performance in tourism: a multicriteria decision analysis approach. Management Decision. 
Lewin, A.Y. (1999). Application of Complexity Theory to Organization Science. Organization Science, 10(3), 215 -215. Lusch, R.F. \& Nambisan, S. 2015. Service innovation: A service-dominant logic perspective. MIS quarterly, 39(1).

Malhotra, N.K. (2010). Marketing research: an applied orientation. $6^{\text {th }}$ global ed. Upper Saddle River, New Jersey: Pearson.

Mennens, K., Van Gils, A., Odekerken-Schröder, G. \& Letterie, W. (2018). Exploring antecedents of service innovation performance in manufacturing SMEs. International Small Business Journal, 36(5), 500-520.

Neuman, W.L. (2011). Social research methods: qualitative and quantitative approaches. $7^{\text {th }}$ ed. University of Wisconsin, USA; Pearson.

Pantano, E. \& Viassone, M. (2014). Demand pull and technology push perspective in technology-based innovations for the points of sale: the retailers' evaluation. Journal of Retailing and Consumer Services, 21(1), 43-47.

Prajogo, D.I. (2016). The strategic fit between innovation strategies and business environment in delivering business performance. International Journal of Production Economics, 171, 241-249.

Retail Motor Industry. (2018). Accredited Members [Online] Available from: https://www.rmi.org.za/findaccredited-members/ (Accessed: 22 -01-2018)

Sundbo, J., Sundbo, D. \& Henten, A. (2015). Service encounters as bases for innovation. The Service Industries Journal, 35(5), 255-274.

Thakur, R. \& Hale, D. (2013). Service innovation: A comparative study of US and Indian service firms. Journal of Business Research, 66(8), 1108-1123.

Tseng, M.L., Wu, K.J., Chiu, A.S., Lim, M.K. \& Tan, K. (2019). Reprint of: Service innovation in sustainable product service systems: Improving performance under linguistic preferences. International Journal of Production Economics, 217, 159-170.

Tustin,D.H., Ligthelm, A., Martins, J.H., \& Van Wyk, De J. 2005. Marketing research in practice. $1^{\text {st }}$ ed. Pretoria: Unisa Press.

Van Tonder, E., Petzer, D.J. \& Van Zyl, K. (2017). A mediated model of relationship quality factors affecting behavioural intention at a luxury motor vehicle dealership. European Business Review, 29(1), 43-60.

Witell, L., Anderson, L., Brodie, R.J., Colurcio, M., Edvardsson, B., Kristensson, P., Lervik-Olsen, L., Sebastiani, R. \& Wallin Andreassen, T. (2015). Exploring dualities of service innovation: implications for service research. Journal of Services Marketing, 29(7), 436-441.

Yanadori, Y. \& Cui, V. (2013). Creating incentives for innovation? The relationship between pay dispersion in R\&D groups and organisation innovation performance. Strategic Management Journal, 34(12), 1502-1511.

Zhang, M., Zhao, X., Voss, C. \& Zhu, G. (2016). Innovating through services, co-creation and supplier integration: cases from China. International Journal of Production Economics, 171, 289-300. 